\title{
PENGGUNAAN MEDIA DALAM PEMBELAJARAN BAHASA INDONESIA DI SMP
}

\author{
Sari Martiningsih \\ SMP Negeri 3 Baureno \\ Posel : sarimartiningsih@gmail.com
}

\begin{abstract}
Abstrak: Tujuan penelitian ini adalah mendeskripsikan secara objektif tentang: (1) jenis-jenis media pembelajaran bahasa Indonesia, (2) aktivitas pemanfaatan media pembelajaran bahasa Indonesia, dan (3) prestasi belajar siswa sehubungan dengan pemanfaatan media pembelajaran bahasa Indonesia di SMP Negeri 3 Baureno. Untuk mencapai tujuan di atas, penelitian ini menggunakan pendekatan kualitatif. Sumber data dalam penelitian ini adalah jenis-jenis media pembelajaran bahasa Indonesia yang digunakan guru, aktivitas pemanfaatan media pembelajaran, dan prestasi belajar siswa yang ditunjukkan dengan nilai ulangan harian. Data dikumpulkan melalui observasi, wawancara, dan dokumentasi.Berdasarkan analisis data yang dipaparkan secara deskriptif kualitatif diperoleh simpulan berikut (1) jenis media pembelajaran bahasa Indonesia yang digunakan berupa media pembelajaran konvensional, (2) aktivitas pemanfaatan media pembelajaran bahasa Indonesia yang dilakukan guru terletak pada kreativitas dan kemampuan guru memodifikasi media pembelajaran yang digunakan sehingga media yang konvensional tersebut memiliki nilai kebaruan karena keluwesan dalam penggunaannya, dan (3) prestasi belajar siswa sehubungan dengan pemanfaatan media pembelajaran bahasa Indonesia sangat memuaskan, baik pada aspek pembelajaran keterampilan berbahasa maupun pada aspek pembelajaran sastra.
\end{abstract}

Kata kunci: penggunaan media, media pembelajaran

Abstract: Target of this research is to describe objectively about: (1) the kinds of Indonesian learning media, (2) the activities use media in learning of Indonesian language, and (3) the achievement of the students of SMP Negeri 3 Baureno referring to the usage of media in learning Indonesian language.To reach the target above, this research use qualitative approach. Source of data in this research is kinds of learning media used by Indonesian teachers, the teaching learning activities that use the learning media, and the students' achievement posed at with daily test. The data collected through observation, interview, and documentation.Based on the data analysis which is described descriptive qualitative obtained the following conclusions (1) the kinds of learning media used by the Indonesian teachers in the form of conventional media, (2) the activities that use the learning media applied by the Indonesia teachers depend on the creativity of the teacher to modify the media so that the conventional media have new value because supple in its use, and (3) the achievement of students grade VII of SMP Negeri 3 Baureno referring to the usage of media in learning Indonesian language very gratifying, both aspect of language skills and aspect of language art.

Keyword: usage of media, learning media 


\section{PENDAHULUAN}

Di dalam kurikulum bahasa Indonesia tahun 2004 dinyatakan bahwa pengajaran Bahasa dan Sastra Indonesia diarahkan agar siswa terampil berkomunukasi dan fungsi utama sastra adalah sebagai penghalusan budi, peningkatan rasa kemanusiaan dan kepedulian sosial, baik secara lisan maupun tertulis. Untuk mencapai itu, siswa hendaknya lebih banyak dilatih menggunakan bahasa untuk berkomunikasi, sedangkan pengajaran sastra ditujukan untuk meningkatkan kemampuan siswa dalam menikmati, menghayati, dan memahami karya sastra. Pernyataan ini menunjukkan bahwa pembelajaran bahasa Indonesia berdasarkan kurikulum Bahasa Indonesia tahun 2004 menggunakan pendekatan komunikatif.

Pendekatan komunikatif lahir sebagai jawaban ketidakpuasan para ahli terhadap pendekatan yang dianut sebelumnya, yakni pendekatan struktural. Pendekatan struktural yang menekankan pembelajaran bahasa pada kemampuan siswa memahami kaidah bahasa atau pengetahuan bahasa. Hal ini menyebabkan pengetahuan siswa tentang bahasa tinggi tetapi tidak mampu menggunakannya.

Pada umumnya guru pendidikan bahasa Indonesia menggunakan metode mengajar secara kovensional, yaitu guru banyak mengajarkan teori-teori, faktafakta, dan masalah-masalah dengan metode ceramah saja, sedangkan siswa hanya mendengarkan, mencatat dan menghafalkannya saja. Dalam proses belajar-mengajar yang seperti itu hanya akan melahirkan manusia terdidik dengan intelektual statis dan kurang kreatif (Sidi, 2000).

Agar tidak terjadi hal-hal seperti di atas, maka guru perlu menerapkan suatu metode yang dapat merangsang minat dan kreativitas siswa terhadap materi pelajaran, yaitu dengan menggunakan media pendidikan sebagai alat bantu mengajar sehingga perubahan yang diinginkan pada diri siswa dapat tercapai (Rachman, 2002).

Salah satu kemampuan dasar yang harus dimiliki oleh guru adalah kemampuan menggunakan media pendidikan maupun sumber belajar. Pendayagunaan media pendidikan dan sumber belajar dapat berupa penggunaan alat peraga buatan guru, pemanfaatan alam sekitar untuk belajar, pemanfaatan perpustakaan dan pemanfaatan fasilitas teknologi pendidikan yang lain. Kemampuan dalam membuat alat peraga sederhana, memilih media pendidikan, mengorganisasikan media pendidikan baik dalam tahap perencanaan maupun pelaksanaan dan merawat serta menyimpan media pendidikan adalah penting dalam upaya meningkatkan mutu pendidikan. Hal tersebut merupakan caracara kreatif yang dapat dilakukan oleh guru dalam kegiatan mengajar.

Sejalan dengan program peningkatan mutu pendidikan, tidaklah berlebihan apabila penggunaan media pendidikan dalam kegiatan belajar mengajar tidak dapat ditawar-tawar lagi dan merupakan suatu alternatif yang harus ditempuh bila menginginkan daya serap yang tinggi dan mutu pendidikan yang memadai. Selama ini penggunaan media pendidikan dalam kegiatan belajar mengajar boleh dikatakan belum dikembangkan bahkan mungkin belum dikenal oleh sebagian guru. Memang di sekolah-sekolah banyak dijumpai berbagai macam media pendidikan, tetapi dalam kenyataannya pemanfaatan dan penggunaannya belum intensif.

Sekolah memerlukan guru yang memiliki kompetensi mengajar dan 
mendidik yang inovatif, kreatif, manusiawi dan cukup waktu untuk menekuni tugas profesionalnya, yang dapat menjaga wibawa di mata peserta didik dan masyarakat, serta mampu meningkatkan mutu pendidikan. Guru yang memiliki sifat kreatif dan sifat profesional dalam pelaksanaan proses belajar diperlukan untuk meningkatkan mutu pendidikan.

Seorang guru yang ingin mengembangkan kreativitas pada siswanya terlebih dahulu harus berusaha agar guru itu sendiri kreatif. Guru sebaiknya berusaha untuk menghadapi masalah mengajar tersebut sebagai suatu tantangan yang kreatif.

Penerapan teknologi pendidikan, khususnya dalam pemanfaatan media pendidikan dalam kegiatan belajar mengajar oleh guru masih dalam kondisi memprihatinkan. Sehubungan dengan itu, sudah selayaknya jika guru mengerti apa dan bagaimana kegiatan belajar mengajar yang efektif dan efisien, serta peranan dari media pendidikan itu sendiri dalam kegiatan belajar mengajar.

Untuk meningkatkan keberhasilan suatu pembelajaran, peran guru sangatlah penting dalam kegiatan belajar mengajar. Guru dituntut untuk aktif dan kreatif dalam kegiatan pembelajaran karena dapat merangsang siswa dalam belajar yang pada gilirannya hal tersebut dapat meningkatkan prestasi belajar siswa.

Pemanfaatan media pendidikan sesuai dengan fungsinya berguna untuk memperlancar proses belajar mengajar sehingga memperbesar daya serap siswa terhadap materi pelajaran. Media pendidikan bahasa Indonesia yang secara kuantitas sedikit tersedia di sekolah tidak mempunyai arti apa-apa tanpa adanya kreativitas dalam memanfaatkan media pendidikan tersebut.
Secara umum penelitian ini bertujuan untuk memperoleh deskripsi secara obyektif tentang penggunaan media dalam pembelajaran bahasa Indonesia di SMP Negeri 3 Baureno tahun pelajaran 2011/2012.

\section{METODE PENELITIAN}

Penelitian ini menggunakan pendekatan kualitatif karena peneliti ingin menjelaskan secara deskriptif tentang penggunaan media dalam pembelajaran bahasa Indonesia di SMP Negeri 3 Baureno tahun pelajaran 2011/2012. Selain itu, pendekatan ini menyajikan secara langsung hakikat hubungan peneliti dan responden tidak hanya terbatas pada pengumpulan data, tetapi meliputi analisis dan interpretasi terhadap data (Winarto, 1990).

Berdasarkan tujuan tersebut, maka penelitian ini cocok menggunakan metode kualitatif. Metode ini sebagai prosedur penelitian yang menghasilkan data deskriptif berupa kata-kata tertulis atau lisan dari orang-orang dan perilaku yang dapat diamati (Bogdan dan taylor, 1975 dalam Moleong, 2000).

Jenis penelitian adalah interaksi simbolik seperti yang dikemukakan Glaser dan Strauss yang berupaya untuk membangun "teori berdasar data" (grounded theory) dapat dianggap sebagai salah satu upaya serius untuk mengembangkan metodologi interaksionis simbolik (Mulyana, 2001).

Data dalam penelitian ini adalah tindakan pemanfaatan media pembelajaran dengan subjek guru dan siswa dengan sasaran kreatifitas pemanfaatan media Pembelajaran bahasa Indonesia. Jenis tindakan pemanfaatan media pembelajaran bahasa Indonesia dalam penelitian ini berupa: (1) pemilihan jenis-jenis media pembelajaran bahasa Indonesia, (2) aktivitas guru 
dalam menggunakan media pembelajaran bahasa Indonesia, dan (3) prestasi belajar siswa.

\section{PEMBAHASAN}

Secara umum, media pembelajaran bahasa Indonesia yang digunakan guru adalah media yang sudah ada atau konvensional. Dengan kata lain, guru tidak menggunakan media buatannya sendiri. Jenis media pembelajaran konvensional yang digunakan tersebut berupa (1) media pandang, (2) media dengar, dan (3) media pandang dengar. Media pandang non proyeksi yang digunakan guru berupa gambar seri, wall chart, reading box, dan reading machine sedangkan papan tulis, papan flanel, papan magnetis, papan tali, papan selip, flash card, kubus struktur, bumbung substitusi, kartu gambar, modul dan media pandang berproyeksi seperti OHP, slide, film, strips, film loop, episcope tidak digunakan oleh guru. Media dengar yang digunakan guru berupa rekaman (tape recorder), radio, sedangkan piringan hitam tidak digunakan oleh guru. Pada media pandang dengar guru hanya menggunakan VTR sedangkan sound slide, film suara, dan televisi tidak digunakan oleh guru.Menggunakan media tersebut tersebar pada semua aspek pembelajaran keterampilan berbahasa maupun pada aspek pembelajaran sastra.

Media yang digunakan guru pada aspek pembelajaran keterampilan berbahasa adalah media konvensional. Dalam bahasa lain guru tidak membuat sendiri media pembelajaran untuk siswasiswanya. Media pembelajaran dimaksud adalah media pandang non proyeksi berupa gambar seri, wall chart, reading box, reading machine; media dengan berupa VTR. Media pembelajaran bahasa lainnya baik dari jenis media pandang, media gambar, dan media pandang dengar tidak digunakan. Penjelasan lebih rinci tentang penggunaan media pembelajaran tersebut akan diuraikan berikut ini.

Dalam pembelajaran menyimak guru menggunakan media dengar berupa radio. Penggunaan media ini dimasudkan untuk mendukung indikator pencapaian hasil belajar dapat mengingat butiran secara rinci/hal penting tentang informasi yang didengar dari berbagai media dan dapat memberikan komentar dengan rincian yang relevan dan memperhatikan penggunaan bahasa sesuai yang didengar. Kedua indikator tersebut termuat dalam kompetensi dasar 'mendengarkan informasi'.

Data ini diperoleh dari hasil wawancara yang telah terekam seperti berikut ini."Untuk pembelajaran menyimak saya biasanya memfungsikan media berupa radio. Media ini selain murah, mudah didapat dan juga sudah pasti dengan tampilan acara/berita aktual sehingga anak-anak tertarik mendengarnya".

Untuk memperkuat kebenaran data tersebut, penulis juga meneliti dokumen berupa persiapan mengajar guru. Ternyata benar pada komponen media pembelajaran tertulis 'siaran radio'.Dalam pembelajaran berbicara guru menggunakan media pandang dengar berupa TVR (Video Tape Recorder). Penggunaan media ini dimaksudkan untuk mendukung indikator pencapaian hasil belajar 'dapat menceritakan pengalaman yang paling mengesankan dengan menggunakan pilihan kata dan kalimat yang menarik sehingga pendengar bisa membayangkan suasana yang diceritakan' yang termuat dalam kompetensi dasar 'bercerita'. Data ini terlihat dalam dokumen persiapan mengajar guru. 
Dalam pembelajaran berbicara guru menggunakan media pandang dengar berupa TVR (Video Tape Recorder). Penggunaan media ini dimaksudkan untuk mendukung indikator pencapaian hasil belajar 'dapat menceritakan pengalaman yang paling mengesankan dengan menggunakan pilihan kata dan kalimat yang menarik sehingga pendengar bisa membayangkan suasana yang diceritakan' yang termuat dalam kompetensi dasar 'bercerita'. Data ini terlihat dalam dokumen persiapan mengajar guru.

Untuk mendukung kebenaran data di atas, peneliti mengadakan wawancara dengan salah seorang murid yang terekam sebagai berikut ini.

"Kami pernah diminta oleh guru kami untuk menceritakan pengalaman kami yang paling mengesankan. Sebelum bercerita, terlebih dahulu kami disuruh menyaksikan rekaman cerita terbaik kakak kelas kami tahun lalu”.

Di samping itu, guru juga menggunakan media dengar berupa radio. Penggunaan media ini dimaksudkan untuk mendukung indikator pencapaian hasil belajar 'dapat menyampaikan informasi dari berbagai media yang sudah diringkas dengan menggunakan kalimat yang singkat, padat, dan mudah dipahami' yang termuat dalam kompetensi dasar' menyampaikan pesan informasi'. Data ini diperoleh dari dokumen persiapan mengajar guru.

Pada aspek membaca, guru mengadakan media pandang non proyeksi berupa reading box. Penggunaan media ini dimaksudkan untuk mendukung indikator pencapaian hasil belajar 'dapat menemukan kata tertentu dan memilih maknanya secara cepat dan tepat sesuai dengan konteks yang diinginkan' dan 'dapat menjelaskan kepada orang lain cara menggunakan kamus' yang termuat dalam kompetensi dasar 'membaca memindai'. Data ini diperoleh dengan melihat dokumen persiapan mengajar yang dibuat guru bahasa Indonesia. Di dalamnya, pada komponen media dan alat peraga tertulis reading box.Selain reading box, dalam dokumen itu juga dijumpai penggunaan media reading machine. Media ini terdapat dalam persiapan mengajar yang memuat kompetensi dasar 'membaca cepat' dengan indikator pencapaian hasil belajar' dapat menentukan gagasan pokok secara cepat' dan 'dapat menceritakan kembali isi teks secara lengkap'.

Untuk membuktikan kebenaran bahwa media itu dipergunakan sesuai dengan yang tertera dalam dokumen, peneliti mengadakan observasi terhadap proses pembelajaran pada indikator pencapaian hasil belajar yang lain. Dalam observasi diketahui bahwa untuk indikator pencapaian hasil belajar 'dapat menjelaskan isi tabel, diagram', dan 'dapat mengajukan pertanyaan tentang isi tabel/diagram' yang termuat dalam kompetensi dasar 'membaca intensif', guru memang menggunakan media dalam pembelajarannya. Media tersebut adalah media pandang non proyeksi berupa wall chart yang digantungkan pada papan tulis. Dengan penggunaan media tersebut siswa secara spontan membaca dalam hati tabel/diagram dalam wall chart yang digantung itu.

Dalam pembelajaran menulis, guru menggunakan media pandang non proyeksi berupa gambar seri. Penggunaan media ini dimaksudkan untuk mendukung indikator pencapaian hasil belajar 'dapat menulis surat pribadi dengan memperhatikan sistematika surat dan struktur kalimat yang komunikatif yang termuat dalam kompetensi dasar 
'menulis surat'. Data ini diperoleh dari dokumen persiapan mengajar guru, yakni pada komponen media pembelajaran tertulis gambar seri.

Dokumen berupa persiapan mengajar tidak menjamin bahwa apa yang telah dilakukan seorang guru sesuai dengan apa yang tertera dalam persiapan mengajarnya. Karena itu, peneliti dalam menjaring data tidak hanya terfokus pada satu instrumen. Paling tidak dengan menggunakan berbagai instrumen, kelemahan dari satu instrume dapat tertutupi oleh kelebihan instrumen yang lain. Demikian sebaliknya.

Instrumen-instrumen

yang dimaksud dalam penelitian ini adalah wawancara dan observasi. Dalam wawancara dengan siswa, khususnya untuk mengorek keterangan tentang penggunaan media pada pembelajaran bahasa Indonesia dengan kompetensi dasar 'menulis surat' yang berindikator pencapaian hasil belajar 'dapat menyunting karangan sendiri atau orang lain dengan memperhatikan ketepatan ejaan, tanda baca, pilihan kata, keefektifan kalimat dan keterpaduan paragraf, diketahui bahwa medianya adalah media pandang non proyeksi berupa reading box. Hasil wawancara tersebut terekam sebagai berikut ini."Pernah. Karangan itu ditaruh dalam sebuah kotak yang berisi beberapa karangan. Kami diberi kebebasan memilih karangan dalam kotak itu. Kemudian kami disuruh memperbaiki jika dalam karangan yang kami pilih itu terdapat kesalahan".

Pada kompetensi dasar lain, yakni 'menyunting' dengan indikator pencapaian hasil belajar 'dapat menyunting dengan memperhatikan ketepatan ejaan, tanda baca, pilihan kata, keefektifan kalimat dan keterpaduan paragraf, data diperoleh melalui observasi pada saat guru mengajar. Dalam observasi terbukti bahwa guru memang menggunakan media dalam pembelajarannya. Media yang digunakan tersebut adalah reading box.

Dalam pembelajaran menulis, guru menggunakan media pandang non proyeksi berupa gambar seri. Penggunaan media ini dimaksudkan untuk mendukung indikator pencapaian hasil belajar 'dapat menulis surat pribadi dengan memperhatikan sistematika surat dan struktur kalimat yang komunikatif yang termuat dalam kompetensi dasar 'menulis surat'. Data ini diperoleh dari dokumen persiapan mengajar guru, yakni pada komponen media pembelajaran tertulis gambar seri.

Dokumen berupa persiapan mengajar tidak menjamin bahwa apa yang telah dilakukan seorang guru sesuai dengan apa yang tertera dalam persiapan mengajarnya. Karena itu, peneliti dalam menjaring data tidak hanya terfokus pada satu instrumen. Paling tidak dengan menggunakan berbagai instrumen, kelemahan dari satu instrume dapat tertutupi oleh kelebihan instrumen yang lain. Demikian sebaliknya.

Media yang digunakan guru dalam pembelajaran sastra juga berupa media pembelajaran konvensional. Dalam semua aspek pembelajaran sastra tidak ditemukan penggunaan media buatan guru sendiri sehingga nilai kebaruan dari sebuah media kurang nampak. Media pembelajaran yang digunakan guru dimaksudkan adalah media pandang non proyeksi berupa gambar seri dan reading box; media dengar berupa rekaman (tape recorder); dan media pandang dapat berupa VTR.

Dalam pembelajaran berbicara sastra (bersastra lisan), guru menggunakan media dengar berupa rekaman. Penggunaan media ini 
dimaksudkan untuk mendukung indikator pencapaian hasil belajar 'dapat berbalas pantun secara berkesinambungan dengan memperhatikan ketepatan syarat-syarat pantun' yang termuat dalam kompetensi dasar 'berbalas pantun'. Data ini terlihat dalam dokumen persiapan mengajar guru.

Untuk mendukung kebenaran data di atas, peneliti mengadakan wawancara dengan salah seorang murid yang terekam sebagai berikut ini.

"Kami senang sekali jika menerima pelajaran pantun. Terutama jika kami diminta saling berbalas pantun dengan siswa lain. Mula-mula memang sulit. Tetapi setelah guru kami memperdengarkan rekaman berbalas pantun melalui tape, kami akhirnya lebih tertarik melakukannya."

Selain dengan siswa, peneliti juga mewawancarai guru bahasa Indonesia. Hasil wawancara tersebut terekam sebagai berikut ini.

"Menggunakan media pembelajaran jauh lebih menguntungkan daripada tidak menggunakan media. Ketika saya membawa tape recorder ke dalam kelas misalnya, anak-anak langsung diam tanpa diperintah. Mereka tertarik dengan benda yang saya bawa dan tidak sabar menunggu apa yang akan saya lakukan. Ini membuktikan dengan membawa media saja ke dalam kelas, penguasaan kelas sudah tercapai, apalagi jika media pembelajaran itu digunakan”.

Pada aspek membaca sastra, guru menggunakan media pandang non proyeksi berupa reading box. Penggunaan media ini dimaksudkan untuk mendukung indikator pencapaian hasil belajar 'dapat menyebutkan hal-hal yang menarik dari isi cerita anak-anak yang dibaca' yang termuat dalam kompetensi dasar 'membaca cerita'. Data ini diperoleh dengan melihat dokumen persiapan mengajar yang dibuat guru bahasa Indonesia. Di dalamnya, pada komponen media dan alat peraga tertulis reading box. Keabsahan data ini diperkuat oleh pernyataan siswa dalam wawancara yang terekam sebagai berikut ini."Kami senang membaca cerita anakanak. Di sekolah juga kami sering membacanya. Biasanya Pak Guru menaruh berbagai macam cerita anakanak dalam sebuah kotak dan kami bebas memilihnya sesuai selera kami. Setelah itu, kami diminta mencari hal-hal menarik yang kami jumpai dalam cerita yang kami baca".

Mengingat dokumen berupa persiapan mengajar tidak selalu menjamin bahwa apa yang telah dilakukan seorang guru sesuai dengan apa yang tertera dalam persiapan mengajarnya, maka peneliti dalam menjaring data tidak hanya terfokus pada data dokumen saja. Karena itu perlu pendukung kebenaran data dari sumber lain. Sumber lain yang dimaksud adalah siswa sebagai subjek yang terlibat langsung dalam proses pembelajaran. Untuk mengorek keterangan dari siswa, peneliti melakukan wawancara dengan siswa. Dalam wawancara dengan siswa, khususnya untuk mengorek keterangan tentang penggunaan media pada pembelajaran bahasa Indonesia yang tertulis dalam dokumen persiapan mengajar guru diperoleh informasi sebagai berikut ini.

"Pernah. Mula-mula ditunjukkan kepada kami beberapa gambar yang saling berhubungan sehingga seperti cerita bergambar. Setelah cukup mengamati kami diminta untuk membuat puisi lama sesuai dengan gambar dan gambar itu tetap dipajang sampai kami seтиa selesai menulia puisi."

Dengan informasi dari kedua sumber tersebut, peneliti yakin akan keabsahan data yang peneliti peroleh 
sehingga dipandang tidak perlu lagi wawancarai guru atau mengadakan observasi tentang penggunaan media tersebut.

Walaupun dalam pemilihan media guru umumnya menggunakan media konvensional, namun pada aktivitas pemanfaatan media pembelajaran bahasa Indoensia tersebut terdapat adanya kreativitas guru dalam memodifikasi media yang digunakan. Kreativitas guru ini berfungsi meminimalisir kebosanan siswa terhadap penggunaan media yang sebelumnya mungkin sudah dikenalnya. Modifikasi dimaksud berupa pengubahan baik pada segi isi media maupun tujuan yang ingin dicapai melalui penggunaan media tersebut. Modifikasi pada media pembelajaran itu dilakukan guru baik pada aspek pembelajaran keterampilan berbahasa maupun pada aspek pembelajaran sastra.

\section{PENUTUP}

Berdasarkan pembahasan, dapat ditarik beberapa simpulan sebagai berikut ini.

Jenis media pembelajaran bahasa Indonesia yang digunakan berupa media pembelajaran konvensional. Media pembelajaran bahasa Indonesia itu meliputi: (1) media pandang, (2) media dengar, dan (3) media pandang dengar.

Aktivitas pemanfaatan media pembelajaran bahasa Indonesia yang dilakukan guru di SMP Negeri 3 Baureno terletak pada kreativitas dan kemampuan guru memodifikasi media pembelajaran yang digunakan. Pemodifikasian tersebut didasarkan pada (1) hakikat pembelajaran bahasa, yakni belajar berkomunikasi, (2) keefektifan dari penggunaan media terhadap pembelajaran, dan (3) sumber belajar alam dan lingkungan yang harus inklusif di dalamnya. Dengan aktivitas guru ini, media yang konvensional tersebut masih memiliki nilai kebaruan karena keluwesan dalam penggunaannya.

Prestasi belajar bahasa Indonesia siswa kelas VII SMP Negeri 3 Baureno sangat memuaskan, baik pada aspek pembelajaran keterampilan berbahasa maupun pada aspek pembelajaran sastra.Penggunaan media pembelajaran dalam bahasa Indonesia alat rekaman lebih efektif dibandingkan dengan yang lainnya.

\section{DAFTAR PUSTAKA}

Arsyad, Azhar. 2000. Media Pengajaran. Cet. Ke-2. Jakarta: PR. Raja Grafindo Persada.

Bogdan, R.C. \& Biklen, S.H. 1998. Qualitatif Research for Education: an intriduction to Theory and Methods. Boston: Allyn and Bacon, Inc.

Hadi, Sutrisno. 1984. Metodologi Research. Cet. Ke-4. Yogyakarta: Yayasan Penerbitan Fakultas Psikologi UGM.

Mulyana, Deddy. 2001. Metodologi Penelitian Kualitatif; Paradigma Baru Ilmu Komunikasi dan Ilmu Sosial Lainnya. Bandung: PT. Remaja.

Moleong, J. Lexi. Metodologi Penelitian Kualitatif. Bandung: Remaja Rosda Karya.

Sidi, Indra Djati. 2001. Мепији Masyarakat Belajar Menggagas Paradigma BaruPendidikan. Jakarta: PT.Logos Wacana Ilmu. 